\title{
The Spirited Part of the Soul in Plato's Timaeus
}

J O S H W I L B U R *

IN THE TRIPARTITE PSYCHOLOGY of the Republic, Plato characterizes the "spirited" part of the soul as the "ally of reason": like the auxiliaries of the just city, whose distinctive job is to support the policies and judgments passed down by the rulers, spirit's distinctive "job" in the soul is to support and defend the practical decisions and commands of the reasoning part. This is to include not only defense against external enemies who might interfere with those commands, but also, and most importantly, defense against unruly appetites within the individual's own soul. ${ }^{\text {I }}$ Spirit, according to this picture, is by nature reason's faithful auxiliary in the soul, while appetite is always a potential enemy to be watched over and guarded against. In the Timaeus, the spirited part of the soul—or "the part which shares in courage and spirited anger," as Timaeus refers to it-is once again depicted as having a supportive relationship with the reasoning part. Timaeus describes it as being "naturally superior" to the appetitive part, and he explains that the gods placed it in the chest, near the head (the bodily location of the reasoning part), so that it would be able to "hear" the reports and commands issued by the reasoning part, and so that it might help reason restrain the appetitive part if the latter should become unruly (69e-7ob).

There are two noteworthy features of Timaeus's characterization. First, it is clear that some sort of intra-psychic "communication" takes place between the reasoning and spirited parts of the soul. In order to respond to the reports and commands of reason, spirit must first in some sense understand them ('understand' here carrying no specific theoretical weight yet). Through what psychological mechanism does this communication occur, however? While recent commentators have provided some illuminating discussions of intra-psychic communication in the Timaeus, those discussions have focused overwhelmingly on the question how reason communicates with appetite (a topic that the dialogue itself treats in somewhat

${ }^{\mathrm{I}}$ See esp. Rep. 439e-442c, and cf. Phdr. 253d-254e.

* Josh Wilburn is Assistant Professor of Philosophy at Wayne State University.

Journal of the History of Philosophy, vol. 52, no. 4 (2014) 627-652 
more detail). ${ }^{2}$ Little attention has been given to communication between reason and spirit, however, or to how that communication relates to spirit's distinctive role in the soul. The second noteworthy feature of Timaeus's account is that, just as in the Republic, spirit's superior relationship with reason distinguishes it from appetite: in contrast to the obedient spirited part, the appetitive part of the soul continues to be a potentially subversive and disruptive force in the soul. Given that both spirit and appetite belong to the lower, "mortal" part of the soul, how can we account for this crucial difference between them? Why is spirit reliably responsive to the commands of reason in a way that appetite is not?

In this paper I will address both of these features of Timaeus's account, focusing primarily on the first. I will offer what has recently been called an "imagistic" account of the communication between reason and spirit, ${ }^{3}$ arguing that we can account for spirit's responsiveness to the commands and reports of reason, as well as for the distinction between spirit and appetite in this regard, by appealing entirely to the resources of sense-perception and imagination. Christopher Bobonich has recently argued that it is "very implausible" that an imagistic account could be given of spirited cognition and motivation. ${ }^{4}$ I aim to make such an account plausible. I will begin in section I by offering a closer examination of Timaeus 69e-70b, the key passage in which Timaeus characterizes the relationship between reason and spirit. In sections 2 and 3 I will consider and reject two approaches to intra-psychic communication in the Timaeus that have recently been suggested. In particular, I will reject the views (a) that spirit has access to more advanced cognitive resources than does appetite and is therefore capable of understanding rational commands in a way that appetite is not, and (b) that reason communicates with both spirit and appetite through persuasion. In section 4 I will offer my own imagistic account, which will draw on material not just from Timaeus, but also from Philebus and Republic. I will also draw attention to points of continuity between the imagistic account and the theories of Aristotle and Posidonius, and I will conclude with remarks on the distinction between spirit and appetite.

$$
\text { I. TIMAEUS } 69 \mathrm{E}-7 \text { О в }
$$

Let us now turn to the passage in question. After having crafted the divine, immortal part of human souls, Timaeus explains, the Demiurge charged the Lesser Gods with the remainder of human creation (explaining that if hewere to create human beings, they would rival the gods themselves). The gods, in turn, crafted the head as the bodily seat of the immortal soul, and they crafted the rest of the body to act as the soul's vehicle ( $44 \mathrm{~d}-\mathrm{e})$. As the Demiurge had previously explained to them, on account of being tied to a body, the soul would by necessity experience "disturbances" ( $\pi \alpha \theta \dot{\eta} \mu \alpha \tau \alpha)$ - in particular, pleasures, pains, boldness, fear, anger, and hope, which would all be mixed with "unreasoning sense-perception and all-

\footnotetext{
${ }^{2}$ Recent accounts have been offered in Bobonich, Utopia, 3 I 6-26, and "Images"; Kamtekar, "Inculcation," I 30-43; Lorenz, Brute, ch. 6, and "Cognition"; and Moss, "Pictures."

${ }^{3}$ Bobonich ("Images," I 50 ) applies this term specifically to the interpretations offered in Lorenz, Brute, and Kahn, "Discussion," with which I take my own account to be broadly aligned.

4"Images," I 58.
} 


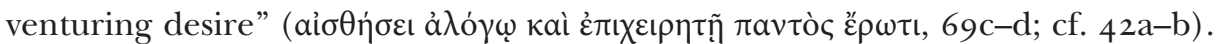
In order to better equip the soul to "master" these disturbances, the lower gods constructed "another kind of soul as well, the mortal kind," which would contain the disturbances. They placed this mortal soul in the body itself, away from the divine part of the soul, so that the latter would be stained "only to the extent that this was absolutely necessary" (69d-e). ${ }^{5}$ Timaeus then explains,

Inside the chest, then, and in what is called the trunk, they proceeded to enclose the mortal type of soul. And since one part of the mortal soul was naturally superior to the other, they built the hollow of the trunk in sections, dividing them in the way that women's quarters are divided from men's. They situated the midriff between the sections to serve as a partition. Now the part of the mortal soul that shares in courage and spirited anger, the victory-loving part, they settled closer to the head, between the midriff and neck, so that it might be able to hear reason and together with it restrain by force the part consisting of appetites, should the latter at any time refuse to willingly obey the commands and reason coming down from the Acropolis. The heart, then, which ties the veins together, the spring from which blood courses with vigorous pulse throughout all the bodily members, they set in the guardhouse. That way, if spirit's might should boil over at a report from reason that some unjust act involving these members is taking place-something being done to them from outside or even something from the appetites within—everything in the body that is perceptive, by perceiving the exhortations and threats through all the narrow vessels, might listen and follow along completely. In this way the best part among them all can be left in charge. $(69 \mathrm{e} 3-70 \mathrm{cI})^{6}$

The picture that emerges from this passage is the following: reason sends "commands" to the rest of the soul, commands which appetite is evidently prone to disobey. When it does disobey, it is spirit's job to assist reason in restraining the appetites "by force." Although it is not stated explicitly, the clear implication is that spirit itself is naturally inclined (or at least, more naturally inclined than appetite) to obey those initial commands. We are also told that reason can "report" acts of injustice, which include both actions by external agents as well as "actions" originating with the appetites within. Presumably, these unjust "actions" of the appetites include instances of disobedience to the rational commands just mentioned. Spirit's distinctive response to reason's reports of injustice is to "boil over" in anger.7 Finally, we learn that reason issues threats and exhortations along with its reports of injustice, and that these messages are delivered through the blood vessels to "everything in the body that is perceptive" ( $\pi \tilde{a} v$ ö $\sigma o v$ ai $\sigma \theta \eta \tau$ тóv $\dot{\varepsilon} v \tau \tilde{\omega} \sigma \dot{\omega} \mu \alpha \tau \iota)$. Spirit, moreover, has a special responsibility for distributing the threats and exhortations throughout the body: the force of its anger causes the heart to beat faster and hence to distribute the relevant information as quickly as possible. According to Timaeus, then, spirit not only comprehends and responds

5ohansen ("Body," IOO-IOI; cf. Natural Philosophy, I 50-54) emphasizes this "cognitive" nature of Timaeus's physiology: "The basic outline of the body . . . shows how the body is so constructed as to aid the intellect in maintaining control over itself and the mortal soul."

${ }^{6}$ Translations of Plato are from Cooper, Plato: Complete Works, with modifications.

${ }^{7}$ Cf. Rep. $440 \mathrm{c}-\mathrm{d}$, where the spirited part becomes "boiling and angry" when the individual believes himself to be suffering an injustice. Taylor (Commentary, 495-99) makes a strong appeal for continuity between the tripartite theory of the Republic and that of the Timaeus; cf. Archer-Hind, The Timaeus of Plato, 255-56. 
to the commands and reports issued by the reasoning part of the soul, but also has a unique role in seeing to it that those commands are carried out by the whole body and soul.

\section{S P IRIT A N D A P P E T I T E}

Whereas spirit is granted its familiar role as "the ally of reason," however, appetite continues to be treated as the primary source of disturbance in the soul: it is naturally prone to disobey the commands of reason and consequently must sometimes be held in check by force. One initially attractive way that we might try to account for these different relationships that spirit and appetite have with reason would be to suggest that the spirited part of the soul is more cognitively sophisticated than the appetitive part, and that it is therefore capable of understanding and communicating with reason in ways that appetite cannot. ${ }^{8}$ There are a couple of reasons why we might be tempted toward this view. First, Timaeus places two explicit cognitive restrictions on the appetitive part of the soul. At 7 ra, he says that the gods knew that this part of the soul—which he compares

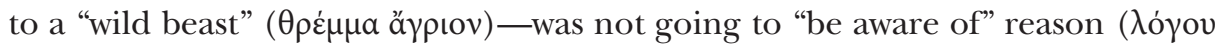

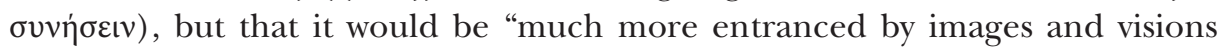

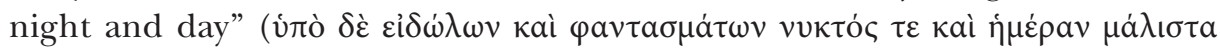

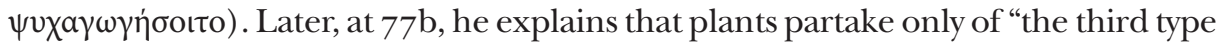

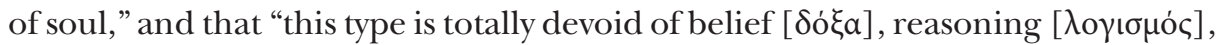
or understanding [voṽc], though it does share in sense-perception, pleasant and painful, and desires." Timaeus thus indicates (a) that appetite is not "aware of" logos, and (b) that the appetitive soul (at least of plants) is incapable of holding beliefs. He never explicitly places either of those restrictions on spirit, however, which might incline us to think that spirit is aware of logos, and that perhaps it can hold beliefs. ${ }^{9}$ The second attraction of this picture is that it would go some way toward explaining spirit's greater affinity with reason: it is more prone to support the commands of reason, we could say, because it has a greater share in rational, or at least semi-rational, capacities.

Despite the draws of this line of interpretation, there are decisive reasons for rejecting it. To begin with, there are obstacles to attributing belief, doxa, to a non-

${ }^{8}$ Brennan ("Spirited Part," I 23) advocates a version of this view, claiming that spirit is "able to listen to reason as appetite cannot," and that while spirit sees the truth less clearly than reason, "appetite sees [the truth] even less clearly than spirit." Likewise, Archer-Hind writes, "Plato's $\theta v \mu$ osı $\delta \dot{c}$. . directly hears and obeys the dictates of reason. If a man is betrayed by his friend, the declaration

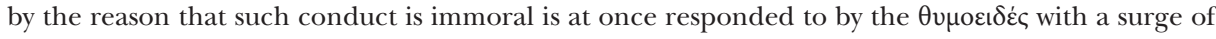
indignation against the friend's baseness. But no such response would come from the ė $₫ \theta v \mu \eta \tau \iota k o ́ v$, which is incapable of understanding the situation" (The Timaeus of Plato, 262-63) . Gill ("Galen vs. Chrysippus," 268-70) draws a similar conclusion; cf. also Karfík, "Mortal Parts," 2 I0-I I. Moss also at least entertains a reading of this sort, stating that the text "leaves open the possibility that spirited passions involve some higher form of cognition" than the perceptual cognition to which appetite seems to be limited ("Pictures," 275). The accounts in Irwin, Ethics, 2 I I-I 2, and Reeve, PhilosopherKings, I 36-37, both of which distinguish spirited desires from appetitive ones on the grounds that the former, but not the latter, are partially dependent on the agent's conception of the good, may also suggest an interpretation of this kind.

${ }^{9}$ For the opposed view that the spirited part of the soul holds its own beliefs, see discussion in Cairns, Psychology, 386-87; and Kamtekar, "Imperfect Virtue." 
rational part of the soul, an objection that I will consider in more detail in the next section. More importantly, though, Timaeus's comments in the long passage quoted above make it clear that not just spirit, but also appetite, is capable of understanding the initial "commands" handed down by reason. His remark that the appetitive part of the soul must be forcefully restrained whenever it refuses to obey reason indicates that, at least sometimes, it does obey reason. ${ }^{10}$ In order to obey reason's commands, however, it must first comprehend them. This is confirmed by the fact that "everything in the body that is perceptive"-which must refer to the soul that is distributed throughout the body, and which includes appetitive

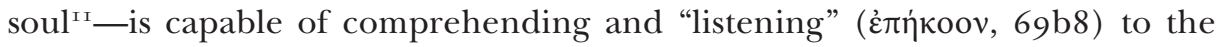
"threats and exhortations" of reason. Therefore, it is clear that the commands, exhortations, and threats handed down by reason are comprehended by spirit and appetite alike. ${ }^{\mathrm{I2}}$

Moreover, if we consider Timaeus's comments on appetite more closely, it is clear that they do not really imply a cognitive distinction between the two lower parts of the soul. It is significant that Timaeus's denial of doxa to appetite appears in the context of his comments on the psychic constitution of plants, which he says possess only the appetitive kind of soul. The fact that he does not explicitly deny belief to the spirited part of the soul in that passage, therefore, implies nothing about the cognitive resources available to spirit; it simply reflects the narrow focus of his discussion at that point. When we turn to Timaeus's claim that appetite is not "aware of" logos, we see that he immediately adds a crucial point: he says that "even if it were in one way or another to have some sort of perception [alı $\sigma \eta \eta \sigma \iota c]$ of them, it would not be in its nature to care $\left[\mu \dot{\varepsilon} \lambda \varepsilon \varepsilon^{\nu}\right]$ about any of the logoi." Coupled with Timaeus's characterization of the relationship between reason and spirit, we can conclude from this remark that what is distinctive about appetite is not that it does not perceive logos, but rather that even if it did, it would not have any regard for it. Inasmuch as the remark implies anything about spirit, then, it implies that if spirit could perceive logos, it would have some regard for it.

\section{PERSUASION AND THE MORTAL SOUL}

Because there is strong evidence for resisting a cognitive distinction between spirit and appetite, and because the apparent evidence in favor of such a distinction fails the test of scrutiny, we should reject this line of interpretation. Spirit and appetite, we can conclude, have available to them the same set of cognitive resources,

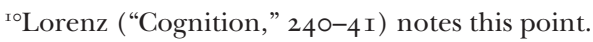

${ }^{11}$ At $73 \mathrm{C}$ Timaeus explains the composition of the marrow that is distributed throughout the body: "[The god] implanted in the marrow the various types of soul [ $\tau \grave{\alpha} \tau \tilde{\omega} v \psi v \chi \tilde{\omega} v \gamma \varepsilon \dot{\varepsilon} v \eta]$ and bound them fast in it." Johansen (Natural Philosophy, I 50-5 I) persuasively defends the view-also advocated in Archer-Hind, The Timaeus of Plato, 272-73; Taylor, Commentary, 522; Carone, "Passions," I Io; and Miller, "Commentary on Brisson," I 8 I - that the "types" of soul Timaeus refers to here are the three soul-"types" of the tripartite soul: the appetitive, the spirited, and the rational. Johansen also provides a response to Cornford (Plato's Cosmology, 294-95), who argues for the alternative view that the "types" of soul refer to the various souls of future living species (described at 90e-92c).

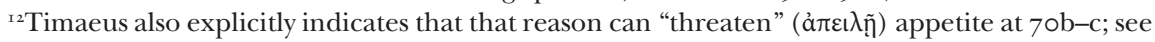
discussion in section 4.I below.
} 
whatever those turn out to be. In line with this conclusion, another proposal has recently been offered by Gabriela Carone: she argues that both spirit and appetite are capable of holding beliefs (where "beliefs" involve propositional structure), and that reason is capable of persuading both of the mortal soul-parts to follow its commands. ${ }^{13}$ She cites a number of pieces of evidence in support of her view: (I) Appetite is capable (as indicated in the previous section) of "obeying" the command and logos coming down from reason, where the word for 'obey' $(\pi \varepsilon i \theta \varepsilon \sigma \theta \alpha)$ is the passive form of the verb 'to persuade' ( $\pi \varepsilon i \theta \omega)$, suggesting that appetite can "be persuaded" (which is Carone's preferred translation). (2) When Timaeus claims that appetite cannot "be aware of" logos at $7 \mathrm{Ib}$, he has just explained that the motivation for placing the appetitive part of the soul far away from the reasoning part in the body is that the gods wanted appetite to cause as little disturbance as possible, "thereby letting the masterful part deliberate in peace about what is beneficial for one and all." Thus, Carone argues, the logos of which appetite is unaware has the specific sense of, as she puts it, "what looks after the interest of (or what is better for) all parts in common." I4 The passage cannot, therefore, be taken as an unqualified denial of any kind of comprehension of logos to appetite. (3) Timaeus, Carone claims, attributes evaluative beliefs to spirit-in particular, beliefs about what is just or unjust. And (4) the denial of belief to appetitive soul at $77 \mathrm{~b}-\mathrm{c}$ need apply only to the souls of plants, whose different physiologies place limitations on their psychic activities and capacities.

In response to (I), we should note that the Greek term 'peithô' has a wide usage that covers far more than what the English term 'persuasion' suggests. As Glen Morrow observes, "It means getting a person to do something that you want him to do, by the use of almost any means short of physical compulsion." "'s Accordingly, the passive 'peithesthai' is often best translated simply as 'obey.' The fact that appetite is capable of peithesthai reason, therefore, does not necessarily mean that reason can "persuade" it—that is, bring about a change in appetite's "beliefs" through convincing speech. It could mean simply that appetite is capable of conforming to reason's judgments without resistance. Indeed, the fact that peithesthai is paired

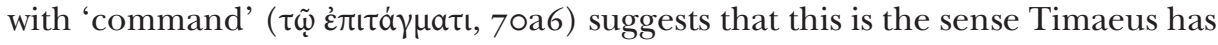
in mind: one obeys commands; one is not "persuaded" by them.

Carone's second point is also dubious. Although it is true that Timaeus's preceding comments characterize the reasoning part of the soul as a deliberator about the overall good of the soul, it is the remarks that follow that specify the cognitive restrictions he means to place on appetite. For he says that although the appetitive part has no perception of logoi, it is entranced by "images and visions" (7 Ia 5-7). By contrasting the kind of content which appetite does not understand with visual content, Timaeus makes it clear that appetite's cognitive limitations

${ }^{3}$ Carone, "Passions," I09-I6. Others have offered similarly "rationalistic" accounts of intra-psychic communication in the Republic, e.g. Morris, "Akrasia in the Protagoras, 218-19; and Singpurwalla, "Reasoning," 255-56, and "Motivation."

${ }^{14}$ Carone, "Passions," I I 2.

${ }_{15}$ "Conception," 236. See also the entry in Liddell and Scott, which lists among the word's passive meanings 'to be prevailed upon,' 'to be won over,' 'to be persuaded,' 'to listen to,' and 'to obey.' 
apply not just to some special subset of logoi, but to logoi in general. As Bobonich observes, the contrast is clearly between "anything linguistic and something nonlinguistic." ${ }^{6}$ Thus we should take Timaeus's remark to indicate that appetite cannot understand, or hold beliefs that contain, propositional structure.

I will return to issues specific to point ( 3 ) in section 4.2 , but for now, it suffices to treat the possibility that spirit holds beliefs in connection with point (4). Carone is certainly correct to point out that the physiology of plants places cognitive restrictions on the appetitive soul that might not apply to the appetitive parts of other animals' souls. (We might speculate, for example, that because plants do not have the organs required for sight or hearing, the perceptual experiences that they have will be significantly impoverished.) Even so, however, there are obstacles to attributing doxa to the lower parts of the soul in the Timaeus. To begin with, Timaeus identifies doxa with the revolving motion of the Circle of the Different $(37 \mathrm{a}-\mathrm{c})$, a motion which is made possible for us (thanks to the wisdom of the Lower Gods' design) by the spherical shape of our heads (44d). Even the elongated shape of other animals' heads, we are told, is not suitable for the revolving motions that constitute human doxa and understanding (9re-92a). Given that Timaeus conceives of doxa as being constituted by a distinct circular motion local to the head, and given that the reasoning part of the soul is the part stationed there, we have strong reason for doubting whether the mortal parts of the soul could hold beliefs. Given their locations in the chest and stomach, where they experience the same rectilinear motions that disturbed reasoning and the Circle of the Different upon the soul's embodiment $(43 \mathrm{a}-44 \mathrm{~b})$, it is unclear how they could engage in anything approximating doxa. ${ }^{17}$ To this we might add that Timaeus accounts for the cognitive capacities of the immortal soul by appealing to its composition out of the materials of Sameness, Difference, and Being (37a, 4 Id-e). In contrast, he is conspicuously silent on the composition of the mortal soul, which leaves open the possibility that its cognitive limitations are determined not just by its incidental location in the body, but also by its very constitution.

In addition to this interpretive worry, there is also a significant philosophical objection to attributing doxa to the mortal soul-parts: doing so threatens to undermine unity of the individual. ${ }^{18}$ If all three parts of the soul, and not just reason, are able to hold beliefs (again, where "beliefs" have propositional structure), then they become no longer genuine "parts" of our soul, but rather cognitively discrete and independent homunculi within us. Such a picture evidently defies phenomenology, however. If all three parts of the soul hold beliefs, then it is inevitable that those beliefs will come into conflict. Yet whereas we often experience

${ }^{16}$ Utopia, $557 \mathrm{n} 45$.

${ }^{17}$ This is in line with Plato's characterization of doxa in his late dialogues as the soul's "silent speech" to itself, speech which has propositional structure and which requires cognitive contact with the Forms (particularly those of Being, Sameness, and Difference), since it involves attributing being to things (Tht. I 86a-I87a; Soph. 262a-264b; Phdr. 249b-c).

${ }^{18}$ Though cf. Dodds (Irrational, $2 \mathrm{I}_{4}$ and 228n32), who thinks that in the Timaeus, "the unity of the individual is virtually abandoned" by its acknowledgement of two distinct "types" of soul (the mortal and immortal). 
ourselves as having conflicting desires (a phenomenon that Plato emphasizes in his Republic 4 argument for tripartition), we do not experience an analogous kind of cognitive conflict involving synchronically held, contradictory beliefs: we do not, that is, feel ourselves believing both $\mathrm{P}$ and not-P at the same time, where $\mathrm{P}$ is some linguistically expressed proposition. ${ }^{19}$ With respect to belief, our consciousness is unified in a way that it could not be if all three parts of the soul held their own distinct doxai. ${ }^{20}$ Given these problems, then, we should reject the idea that the lower soul-parts hold beliefs, and with it the possibility that reason communicates with them through persuasion.

\section{A N I M A G I T I C A G C O U N T}

In light of the conclusions of sections 2 and 3, the alternative account I will offer of reason's communication with spirit (a) will not attribute to spirit cognitive resources or capacities that are superior to those of appetite, and (b) will not attribute to spirit beliefs, the ability to understand the propositional content of reason's beliefs, or the ability to be persuaded by reason. Instead, I will offer an imagistic account of reason's communication with spirit. The central thesis of that position will be the claim that the mortal soul-parts are cognitively limited to the kind of perceptual information that can be conveyed through the faculties of memory, sense-perception, and imagination. Accordingly, the commands, reports, threats, and exhortations issued by the reasoning part of the soul, I will suggest,

${ }^{19}$ The apparent counterexample is to be found in Republic Io (see, for example, discussion in Reeves, Reorientation, 84-86), where Socrates distinguishes between the better part of ourselves that "believes" in accordance with reasoning and measurement (e.g. that an apparently bent stick submerged in water is actually straight), and the foolish part of ourselves that simultaneously "believes" in accordance with mere appearances, "contrary to measurement." Although Plato attributes contradictory (or at least contrary) beliefs to a single individual here, this does not necessarily represent a counterexample to the claim that we do not ordinarily believe both $\mathrm{P}$ and not-P simultaneously. For the Book Io passage offers no clear indication that the two opposed beliefs both have propositional structure. Given that one of the beliefs is based on reasoning, we can assume that it may contain such a structure, e.g. "The stick is actually straight." However, given that the foolish belief is formed directly from perceptual experience, with no apparent mediation by the soul's own rational activities, we may suppose - the text at any rate leaves it open - that that belief's content is isomorphic with the content of the perceptual experience itself. We may suppose, that is, that the belief has an imagistic, non-linguistic form. While later dialogues may cast doubt on whether such a state constitutes a "belief" (see n. I7 above), Republic Io seems to operate with a more permissive use of the term. If this reading is correct, then Book Io does no more than affirm that we can simultaneously believe something is one way while finding that it looks another way. Cf. Lorenz, Brute, 73, which argues that the "foolish" beliefs of Book Io fall short of Plato's later, considered criteria for belief, but that "they are very much like beliefs. They involve the soul's acceptance that things are some way or other." Lorenz (Brute, I09) offers a similar analysis of the three soul-parts' "shared belief" ( $\dot{\mu} \mu \mathrm{o} \delta \mathrm{o} \xi \tilde{\omega} \sigma \iota)$ that reason ought to rule at Rep. $442 \mathrm{~d}$. He suggests that the term may indicate no more than "acquiescence of the non-rational parts in the course of action that reason prescribes."

${ }^{2 \circ}$ Price ("Subjects," Io) takes the unity of consciousness to be a decisive obstacle to construing the soul-parts as three distinct psychological subjects. However, his conclusion is perhaps too strong: the fact that conscious thinking is unified suggests that there is a single subject of beliefs proper in our souls, but it does nothing to suggest that there is a single subject of motivations in our souls. Indeed, the fact of motivational conflict seems to tell against the latter in much the same way that the unity of consciousness tells in favor of the former. 
take the form of quasi-perceptual representations or "imaginings." (It should be noted here that although I will the term 'images' to refer to such mental states, their content is not restricted to the visual: we are, of course, also capable of imagining what it is like to hear, taste, touch, and smell things. Moreover, we can also imagine how we feel when we do or experience things-pleased or pained, happy or sad, proud or ashamed.) Appetite and spirit understand reason's messages, in other words, because they "perceive" them.

\section{I. Sense-Perception and Imagination}

There are several reasons for thinking that communication between reason and the mortal soul-parts takes place through a perceptual, non-linguistic mode. First, whereas Timaeus emphasizes that the mortal soul is to contain sense-perception (69c-d; cf. 42a-b and 6Ic-d), he does not equip it with any further capacities or states that could account for its comprehension of logos. In fact, he explicitly says that the sense-perception to which they have access is "irrational," alogos (69d4). Second, we have noted that part of spirit's job in the soul is to ensure that the "threats and exhortations" issued by reason are distributed throughout the body. The vehicle by which they are distributed, moreover, is the blood, "through all the narrow vessels." Significantly, in Timaeus's account of sense-perception, he characterizes blood as the main carrier of perceptual information, and the blood vessels as the conduits for the transmission of that information. ${ }^{2 \mathrm{I}}$ Timaeus describes taste, for example, as the process in which "earth-like parts penetrate the area around the tiny vessels that act as testers for the tongue and reach down to the heart" (64c6- $\left.\mathrm{d}_{3}\right)$, and sound is "the stroke of air inflicted through the ears on the brain and blood and transmitted to the soul" (67b2-4). ${ }^{22}$ Sight, he explains, occurs when the "internal fire" within us, coming into contacts with external objects and the "kindred fire" outside, "transmits the motions of whatever it comes in contact with as well as of whatever comes in contact with it, to and through the whole body until they reach the soul" $\left(45 \mathrm{c} 7-\mathrm{d}_{3}\right)$. Dreams are caused, he says, when this internal fire is shut up inside us and produces images similar to the

\footnotetext{
${ }^{21}$ Brisson ("Sense Perception," I 57-59) provides a valuable discussion of this feature of Timaeus's account. He explains the choice of blood as the agent of transmission as follows: "Because it is made out of the four elements, it is able, according to the principle that the same is known by the same, to transmit information coming from any variety of sensible things made out of the same four elements. And because there is a lot of fire in it-fire being the most mobile element-it has great mobility and consequently it is a very good agent of transmission." Cf. Ganson, "Platonic Approach," 2n4; Schiefsky, "Galen," 269; and Solmsen, "Nerves," I 59-67. On this reading, Timaeus's account has obvious connections to Empedocles's account of thought and perception, which makes blood the primary agent of these processes. Consider Theophrastus's comment on the Empedoclean theory: "We think especially with the blood. For in this part the elements are most blended" (fragment I 68 in Graham, Early Greek Philosophy, vol. I:403).

${ }^{22}$ This translation is the one preferred by Lautner ("Hearing," $235 \mathrm{nI}$ ) and Cornford (Plato's Cosmology, 275). An alternative translation, which follows Ps.-Plutarch, PP 4.I9.I, defines sound as "the stroke of air transmitted by way of the ears, brain, and blood to the soul." This alternative reading — which Brisson ("Sense Perception," I 57) favors—-makes the role of blood in transmitting auditory experiences even more explicit. Even Lautner, however, acknowledges that "the role of blood seems central in the transmission" ("Hearing," 236).
} 
ones produced from outside $(45 \mathrm{~d}-46 \mathrm{a})$. Later, we learn that this internal fire is localized around, and associated with, the blood and veins $(78 \mathrm{~d}-79 \mathrm{~d})$, the blood itself consisting primarily of fire $(78 \mathrm{a}-\mathrm{b})$. Finally, speaking more generally about the construction of the blood vessels, Timaeus explains,

[The lesser gods] next split these veins in the region of the head and wove them through one another, crossing them in opposite directions. They diverted the veins from the right toward the left side of the body, and those from the left toward the right. . . . They did this especially to make sure that the stimulations received by the senses, coming from either side of the body, might register clearly upon the body as a whole. $(77 \mathrm{~d} 6-\mathrm{e} 6)$

While these explanations no doubt raise a number of questions about the physiological and mechanical processes involved, we can bracket those issues for our present purposes. The important point is that Timaeus clearly envisions the blood as having a special role in transmitting sensory information and experiences. The fact that spirit transmits the "threats and exhortations" of reason through the blood, then, suggests that the content of those threats and exhortations is perceptual.

This proposal is confirmed by the language that Timaeus uses in characterizing the process. Reason's messages are delivered, he says, to "everything in the body

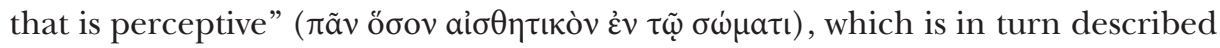
as "perceiving" (ai $\sigma \theta \alpha v o$ orvov) them. ${ }^{23}$ Likewise, as discussed above, Timaeus says that appetite would not be inclined to care about logoi even if it were to have

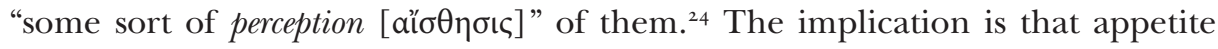
cannot understand logos because it is cognitively limited to the resources of senseperception, and because logos is not the sort of thing that is perceptible. And finally, Timaeus makes it explicit that at least some of reason's messages are perceptual in form: reason "threatens" ( $\dot{\alpha} \pi \varepsilon \mid \lambda \tilde{\eta})$ the appetitive part of the soul by causing frightful images $\left(\varepsilon^{\prime} \delta \omega \lambda \alpha\right)$ to appear to on the shiny surface of the liver, and it encourages appetite by "painting pictures" ( nature (7ra-d).

From all of this we may conclude that the commands, reports, threats, and exhortations that are communicated to appetite and spirit have the form of images with perceptual content. The idea, then, is this: the reasoning part of the soul deliberates about which actions would be best and which actions should be avoided (70e 5-7 гa3), and the beliefs at which it arrives at the conclusion of such deliberation have the form of logoi. Those logoi, however, are also accompanied by (or can be accompanied by) images that illustrate at least some of their content, and it is those images that the mortal soul-parts perceive, understand, and respond

${ }^{23}$ Bobonich (Utopia, 556n43) translates the relevant phrase as "every sentient part of the body," and consequently he takes Timaeus to be suggesting that the body itself responds to the threats and exhortations of reason. In order to make sense of this, Bobonich suggests that Timaeus means no more than that reason's announcements cause physiological changes in the body. Likewise, Zeyl translates the phrase as "every bodily part that is sensitive" (in Cooper, Plato: Complete Works, I27I).

${ }^{24}$ Timaeus further says that the gods knew that appetite was not going to "understand" logos,

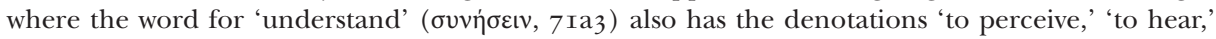
and 'to be aware of.' 
to. But what exactly do the images depict? What constitutes a "threatening" image, for example? Although Timaeus does not make this part of his account explicit, we can fill out some of the details by turning to the Philebus. ${ }^{25}$ In his discussion of "false pleasures," Socrates explains-in terms that closely match the imagistic account I am advocating for the Timaeus - that (at least some of) our perceptual experiences and affective states involve both a "scribe" and a "painter" in our souls $(38 \mathrm{e}-40 \mathrm{e})$. For example, he says, if a man sees something standing in the distance, he might question what it is and silently conclude to himself, "It is a man." This conclusion, Socrates says, is "written" in our souls by the scribe, and that inscription constitutes a belief ( $\delta$ ó $\xi \alpha)$ and a logos. But there is also a "painter" in our souls, who follows the scribe and provides illustrations of the scribe's logoi. This process, moreover, can occur not just in cases of present perceptual experiences, but also in cases that involve remembering the past or anticipating the future. Thus, for example, Socrates says that "hopes" often involve logoi that assert our expectations about the future. "But there are also those painted images [ $\varphi \alpha v \tau \alpha \dot{\sigma} \sigma \mu \alpha \tau \alpha \dot{\varepsilon} \zeta \omega \gamma \rho \alpha \varphi \eta \mu \dot{v} v \alpha]$," he says, "and someone often envisions [ó $\rho \tilde{a}]$ himself in the possession of an enormous amount of gold and of a lot of pleasures as a consequence. And in addition, he

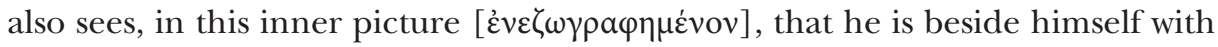
delight" (40a9-I2). Applying the language of this account to the Timaeus, we would say that the mortal soul-parts do not understand or respond to what the scribe writes, but only to what the painter paints. A "hopeful" image, as Socrates characterizes it, is constituted by the agent's imagined depiction of some future, pleasant object, and of himself taking pleasure in that future object. ${ }^{26}$ From this we may speculate that the "threatening" images of the Timaeus would involve depictions of future, painful objects, and of the agents themselves being pained by them. ${ }^{27}$ Thus reason's "threats" would affect appetite by drawing its attention to the painful experiences that are associated with a course of action that reason judges undesirable.

\subsection{Imagination and Spirited Motivation}

This seems straightforward enough in the case of reason's communication with appetite: reason can entice or discourage appetite by causing the individual to imagine future experiences and actions involving bodily pleasure or pain, which

${ }^{25}$ In my reading of the Philebus I largely follow recent accounts offered in Lorenz, "Cognition" (and cf. Brute, 74-94), and Moss, "Pictures," and I defer to their much more detailed treatments of this complex and controversial passage. For discussions relevant to the controversy concerning the content of the scribe's and painter's products, see esp. Dybikowski, "False"; Evans, "Hedonic"; Frede, "Pleasures"; Gosling, "Philebus 35c-4 Ib"; Gosling and Taylor, The Greeks on Pleasure, 43 I-44; Harte, "Philebus on Pleasure"; Kenny, "Reply"; Penner, "Anticipatory"; Russell, Good Life, I76-83 (another account to which I am sympathetic on many points); and Thein, "Self-Awareness." Thein's account, which downplays the role of mental images and takes the content of the "painting" to be propositional ("Self-Awareness," I23-3I), represents the sharpest contrast to the interpretation I present. Thein also suggests that the functions of the painter and scribe cannot be separated or "atomized" ("SelfAwareness," I 25-28), an issue on which n. 48 below may bear.

${ }^{26}$ Cf. Delcomminette, "False Pleasures," 229; and Moss, "Pictures," 268.

${ }^{27}$ Lorenz ("Cognition") develops this line of interpretation at length. 
appetite is naturally inclined to find attractive or repulsive. What makes this account plausible is that what appetite is naturally attracted to and what it naturally finds repulsive-pleasure and pain-have an obvious connection to sense-perception: pleasure and pain are, in fact, perceptual experiences, which is precisely how Timaeus himself characterizes them $(64 a-65 b)$. Because of that, pleasure and pain are experiences that we can imagine, and hence experiences that can be depicted in the images that accompany rational commands. In order for the imagistic account to hold of reason's communication with the spirited part as well, however, it must be the case that what characteristically attracts or repels spirit is something similarly imaginable - that is, communicable in perceptual terms. It is less clear than in the case of appetite, however, precisely what the "images" accompanying reason's logoi could depict that would appeal to, or repel, spirited desire. This difficulty is especially acute if we consider that spirit is said to respond when reason makes judgments about injustice, which does not seem to be a perceptible feature of actions. It is for precisely these reasons that Bobonich has rejected the possibility of offering an imagistic account of spirited motivation. ${ }^{28}$

We should note, to begin with, that Plato himself provides an indication that we should be optimistic about the possibility of accounting for spirited motivation in terms of images. In the Philebus, having offered his account of hopes in terms of the "scribe" and the "painter," Socrates states that "the same account holds in the case of fear, spirited anger, and everything of that sort" (40e). We can expect, then, that he understands passions such as fear and anger to involve a similar conjunction of judgment on the one hand, and a "picture" corresponding to that judgment on the other. Evidently, whatever judgments are involved in anger can be sufficiently "illustrated" to stimulate the relevant spirited emotion.

In order to fill out an account of what such "illustrations" might look like, I turn now to the Republic, where Plato characterizes the spirited part of the soul as

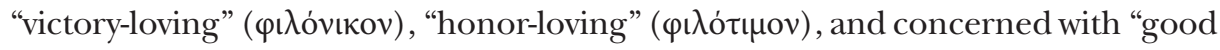

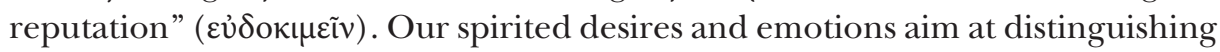
ourselves in ways that earn the honor and esteem of others (as well as our own selfesteem), and at responding to perceived offenses to our sense of honor. Thus the spirited part of the soul is also associated with feelings of anger and shame, and with attitudes of admiration (toward those who distinguish themselves in ways we would like to emulate) and disgust (toward those who act in ways we would be ashamed to emulate) ${ }^{29}$ Because of its characteristic desires, one of the distinctive features of the spirited part of the soul, as the Republic characterizes it, is its malleability. Because spirit aims at honor and admiration, its desires are heavily influenced by what is actually honored and admired in an individual's culture. This influence is

${ }^{28}$ Bobonich comments, "Trying to account for the content of all the psychic items found in the Spirited part—such as anger at injustice, shame, and so on-purely in terms of images is very implausible" ("Images," I 58 ).

${ }^{29}$ For the association of the spirited part of the soul with these attitudes and emotions, see esp. Brennan, "Spirited Part," I09; Cairns, Psychology, 383-84; Cooper, "Theory," I30-36; and Hobbs, Hero. For relevant passages see Rep. 40Id-402a, 439e-440a, 44IC, 549a, 5 5ob, and 58 Ia; Tim. $70 \mathrm{a}-\mathrm{d}$; and Phdr. 253d-254a. 
especially prevalent during youth, when socialization and early education shape the individual's views about what kinds of behavior, and what kinds of individuals, are honorable and worthy of emulation. It is precisely this tendency of spirited desires to be influenced by culture that Plato aims to exploit in his account of early education in the Republic, and it is a large part of what motivates his censorship of poetry. ${ }^{3 \circ}$ The problem with poetry, according to Socrates, is that it can make indecent behavior and characters appear admirable. This has the effect that the individuals exposed to such poetry (especially if they are exposed to it at a young age) aspire to be and act like those characters (or at least, are not ashamed to be or act like them). ${ }^{3 \mathrm{I}}$ So, for example, Homer's depiction of Achilles makes him appear to be an admirable character: he distinguishes himself by acts of physical and athletic dominance, his enemies fear him and tremble at his presence, and his friends conspicuously honor him as a great warrior. This effect on the young individual exposed to a performance of Homer is doubled, moreover, by the admiration of the crowd watching Achilles:

When many people are sitting together in assemblies, courts, theaters, army camps, or in some other public gathering of the crowd, they object very loudly to some of the things that are said or done and approve of others in the same way, shouting and clapping, so that the very rocks and surroundings echo the din of their praise or blame and double it. In circumstances like that, what is the effect, as they say, on a

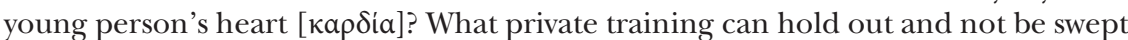
away by that kind of praise or blame and be carried by the flood wherever it goes, so that he'll say that the same things are admirable or shameful as the crowd does, follow the same pursuits as they do, and be the same sort of person as they are? (492b6-c9)

All of these social influences teach the young person what kinds of people, and what kinds of behavior, earn honor. (It is worth noting, in light of Timaeus's psychophysiology, that the effects of this influence are registered on the young person's heart.) As these ideals become internalized, the individual's spirited desires-which naturally aim at honor-will develop accordingly: the individual's spirited sense of pride and shame will be inextricably bound up with the values of the culture in which he or she is raised. In the case of Achilles, the danger is that although Homer makes him appear admirable, and although the crowd honors him with their cheers, Achilles often engages in behavior that Plato considers disgraceful. It is for that reason that Plato wishes to censor, for example, the extreme displays of grief acted out by Achilles upon learning of Patroclus's death (39ra-b). ${ }^{32}$ If the young are exposed to such behavior by an apparently admirable character, Socrates explains, then, if it should ever enter their heads to engage in that kind of behavior during their own times of grief, they will not be ashamed to do so (388d).

${ }^{3 \circ}$ On the "educability" of the thumoeides, see Cairns, Psychology, 386-88; Cross and Woozley, Philosophical Commentary, I 22; Gosling, Plato, 42-45; Hobbs, Hero, 58; Lear, "Learning"; Moss, "Shame"; and Wilburn, "Education."

${ }^{3}$ A typical comment by Socrates to this effect: "Indeed, if we want the guardians of our city to think that it's shameful to be easily provoked into anger at one another, we mustn't allow any stories about gods warring, fighting, or plotting against one another" (378b6-c 3 ).

${ }^{32}$ Hobbs (Hero, I99-2 I9) offers an enlightening account of the importance of Achilles in Plato's account of early education. 
Applying this understanding of spirited motivation to the Timaeus, I suggest the following proposal: the images that constitute or accompany reason's commands and reports depict actions and behavior that the spirited part of the soul has antecedently become inclined, through socialization and education, to be attracted to and repelled by. ${ }^{33}$ Those images may also, we might speculate, draw attention to attendant, perceptible features of the actions that make them seem especially honorable or dishonorable. (Notice that in the passage above Socrates emphasizes the impact of the perceptible expressions of praise and blame-the thunderous sounds of their claps and shouts.) So, for example, an athlete preparing for the Olympic games, who has (rationally) judged that he ought to devote the day to rigorous training, might imagine not just the training itself, but also the crown of victory and the applause of the crowd. Thus, just as the hopeful individual of the Philebus imagined not just gold in the future, but also himself taking pleasure in that gold, so also the Olympian might imagine not just competing in an athletic competition, but also himself being honored and feeling proud for doing so. The effect of imagining an action that the individual has come to identify as a source of honor and pride-as well as the attendant admiration and self-esteem that performing it involves and any conspicuous signs of success in that action-is that the individual's spirited part will be roused to follow reason in pursuing that course of action. It will, that is, eagerly obey reason's "command."

Likewise, reason's "reports" of injustices would involve remembering an offensive past action or imagining an anticipated one, with particular imaginative focus on the features of the action that made it, or would make it (appear to the agent to be) a loss of honor, a public embarrassment, a source of shame and ridicule, etc. If an individual has been treated insultingly by another agent, for example, he might hold the insulting behavior before his memory, while also remembering, say, the presence of his peers at the time. Alternatively, if reason's report is about an injustice sought by the appetites within—say, indulging in an indecent sexual act-the individual might focus his attention on the features of the act that make it indecent, and he might also imagine, for example, the looks of disgust he would receive from others if he were caught. ${ }^{34}$ The effect of such uses of memory and imagination will be that the individual's spirited anger will be roused to support reason in retaliating against the offending agent or in resisting

\footnotetext{
${ }^{33}$ Brennan, in his excellent treatment of the spirited part of the soul, warns that modeling spirit's orientation toward honor on that of "perceptual sensitivity" is misleading: "The mistake that this can lead to is to suppose that there is out there in the world a stuff called 'honor' that spirit is sensitive to in the way that eyes are sensitive to light or colors" ("Spirited Part," I09-IO). In other words, there are no facts of the matter about what is honorable independent of the "institutions of reputation, renown, shame, and so on" that are established by people and societies themselves. Although Brennan's point is well-taken, my account avoids this misstep, in that it affirms precisely the insight that is important to Brennan-namely, that what appeals to the thumoeides is malleable and is determined in the first instance by the culture in which the individual is raised.

${ }^{34}$ In the Laws the Athenian Visitor proposes a law that both promotes and exploits an individual's sense of shame at getting caught in a sexual act. Recognizing that some people will be unable to abstain from sexual indecency completely, he advocates a "second-best" law: "Let it be laid down as a custom in habit and unwritten law, that among them it is noble to engage in these activities if one escapes notice, but shameful if one doesn't escape notice" (84 Ia-b).
} 
his own appetitive urges. If reason commands a particular course of revenge in response to a slight, for instance, then the agent might rouse spirit's support by vividly imagining both the retaliatory act itself and the satisfaction he expects to feel in executing it.

Note that the imagistic interpretation of Plato, in line with the conclusions of Sections 2 and 3, does not require either that spirit respond directly to, or itself believe, the propositional content of reason's judgments, for example, that an unjust act has occurred. (Nor, it should be noted, does it require that the complete content of a rational logos be expressible in the form of an image.) Pace Carone, Plato never actually attributes beliefs about injustice to the spirited part of the soul itself. What Timaeus actually says is simply that when reason announces ( $\pi \alpha \rho \alpha \gamma \gamma \varepsilon \dot{\lambda} \lambda \alpha \nu \tau o \varsigma)$ an injustice, spirit responds by boiling over in anger. Timaeus thus attributes the belief about injustice to the reasoning part of the soul here, and he does not indicate either (a) that as a result of reason's announcement, spirit itself comes to hold a belief about injustice, or (b) that spirit responds in the way that it does because it understands the propositional content of reason's belief. ${ }^{35}$ Timaeus does not, that is, specify the psychological mechanism by which reason's announcement affects spirit, or the form or content it has when it does so. The imagistic proposal is that when reason announces the occurrence of an unjust action, the individual also remembers or imagines that action and its attendant features, and that if the person has come to associate actions of that kind with dishonor and shame, then (precisely because of that association) spirit will be roused to follow reason's lead.

\subsection{Mental Images in Aristotle and Posidonius}

It will be useful here to draw attention to important points of continuity between the imagistic account as I have sketched it and the psychological theories of two later thinkers whose views are indebted to Plato. My hope is that doing so will provide supplementary support for the plausibility of the imagistic account as an interpretation or elaboration of Platonic psychology.

First, consider Aristotle. Jessica Moss has recently offered an illuminating study of ways in which key elements of Aristotle's theory of the emotions is anticipated by Plato's own views. I cannot hope to replicate the richness of her account in the present space, but I would like to point out some important points of overlap between the Platonic and Aristotelian theories that bear on the present discussion. ${ }^{36}$ The first is that, for Aristotle, the faculty of imagination-or phantasia—plays a

${ }^{35}$ Similarly, at Rep. $440 \mathrm{O}$ the spirited part of the soul is aroused "whenever someone believes he is

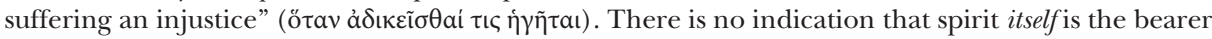
of that belief. Galen comments on this passage: "The belief that one is being wronged belongs to the rational part, while help in combatting the coercive force is the special function of the spirited part" (PHPV.498, 482.I4-I6); cf. remarks in Stalley, "Persuasion," 79.

${ }^{36}$ Moss ("Pictures") argues that Plato's theory anticipates Aristotle's on three specific points: (I) Passions essentially involve pleasures and pains; (2) passions are responses to quasi-perceptual appearances of their objects; and (3) these appearances represent the objects as good or bad. Her second point in effect combines my first and second points below. I take my account to be largely aligned with Moss's, particularly given her emphasis on the role of "pictorial" (i.e. imagistic) content 
prominent role in the emotions, including several emotions that characteristically involve the spirited element of the soul. In the Rhetoric Aristotle describes anger as "a desire, accompanied by pain, for what appears to be revenge in response to

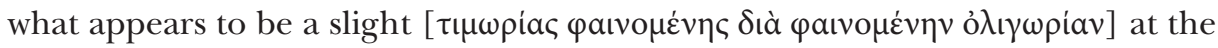
hands of men who have no call to slight oneself or one's friends" (I $378 \mathrm{a} 30-32) .37$ Similarly, he characterizes fear as "a pain or disturbance that results from imagining

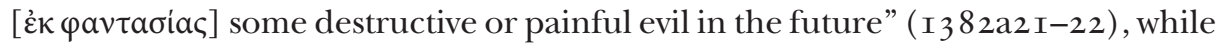

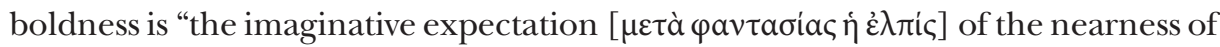
what keeps us safe, and the absence or remoteness of what is fearful" (I383ar6-I8).

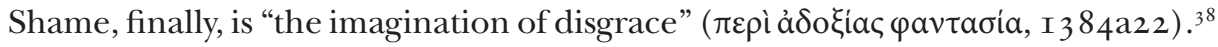

The second point is that, on Aristotle's account, the content of imagination (at least in several of the most noteworthy uses of that faculty) is prominently, perhaps exclusively, perceptual or imagistic. ${ }^{39}$ This is, in fact, a consequence of the relationship between the faculties of sense-perception and imagination in Aristotle's theory: although they are distinguishable in their "being," they are nonetheless in an important sense identical (Insom. 459aI 5-I7). Imagination is made possible by sense-perception ( $D A 427 \mathrm{bI} 5-\mathrm{I} 6,428 \mathrm{bII}-\mathrm{I} 2)$, and instances of imagination are ultimately caused by sensations themselves: imagination is "a movement set up by the sensory faculty while actually discharging its function" (Insom. 459aI7-I 8; cf. DA 428bio-I4). Imaginative content, Aristotle emphasizes, reflects this origin in the processes of sense-perception. The movement that

in Plato's account of the emotions. There are, however, a few points on which our views diverge. First, she seems more willing than I am to allow that emotions of the lower soul-parts, for both Aristotle and Plato, may be "belief-like" in including something like propositional content ("Pictures," 262 , 266). Second, and relatedly, she wants to insist that all three parts of the soul can persuade and be persuaded by one another, as well as agree or disagree ("Pictures," 276). Finally, I am not convinced that her third point is an accurate way to characterize Plato's theory, largely for reasons presented in Ganson, "Rational/Non-Rational."

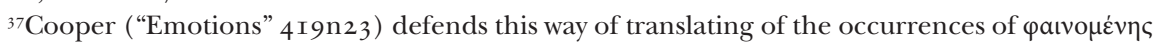

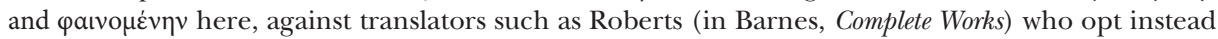
for "conspicuous" and its synonyms.

${ }^{38}$ For defense of the Rhetoric as a source of Aristotle's views about the emotions, see Cooper, "Emotions"; Fortenbaugh, Aristotle on Emotion, I6; Nehamas, "Pity," 295; Nieuwenburg, "Emotions and Perceptions," 86-87; and Striker, "Emotions in Context," 287-88. There is some controversy concerning the question whether the references to phantasia in the Rhetoric's discussion of the emotions are to be taken to refer to the faculty of phantasia that Aristotle describes in the other works, or whether the references lack this technical sense. Moss ("Pictures," 262) and Niewenburg ("Emotions and Perceptions," 89-92) defend the former position, contra Nussbaum, "Rational Persuasion."

${ }^{39}$ I take this claim to be at least relatively moderate, particularly given the parenthetical qualifying phrase. Nonetheless, Aristotle's theory of phantasia is an especially contentious topic among commentators, and I do not have the space to engage in that debate by defending an interpretation of Aristotle in the present context. Certainly the claims I make about Aristotle are not new, however. For some discussion of the content of phantasiai, see the following selections from a very extensive body of secondary literature: Barney, "Appearances," 289-93; Caston, "Imagination," 46-52; Everson, Aristotle on Perception, 2 I0-28; Frede, "Cognitive," 294; Gallop, Sleep, 20-2 I; Lorenz, Brute, I I3-8 5; Modrak, "Revisited," and Power, 82-I07; Nussbaum, Aristotle's De Motu, 22 I-4I; Schofield, "Aristotle," 264-66; and Wedin, Mind, 29-30. I take my interpretation to be most in line with the accounts of Barney, Modrak, and especially Lorenz, and to stand in most contrast to the accounts of Schofield and Nussbaum, both of whom seek to downplay the significance of imagistic content in applications of phantasia. 
constitutes an instance of imagination "is necessarily similar in character to the sensation itself" (DA 428bi 4 ; cf. 429a4-5). It is, as Aristotle puts it in the Rhetoric,

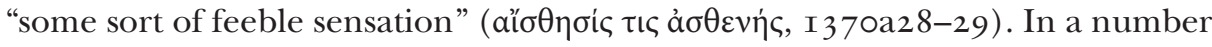
of places, moreover, Aristotle draws attention to the imagistic and perceptual nature of the content of imagination: he describes imagination as "that in virtue of which an image [ $\varphi \alpha ́ v \tau \alpha \sigma \mu \alpha]$ arises in us" (DA 428a I-2); memories are "something

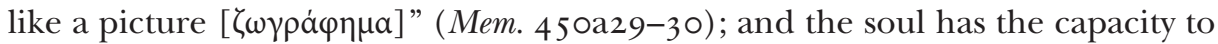
deliberate about what is going to happen by means of images "just as if it were seeing" (DA $43 \mathrm{rb} 7)$.

From this we can reasonably conclude that, for Aristotle, the role that phantasia plays in emotional states involves the vivid use of mental images. If this is right, then the instances of imagination involved in emotions such as anger and shame will involve actually "picturing," for example, acts of slight, revenge, or dishonor (or, in the case of fear, terrifying events or circumstances), in much the same way that I have suggested emotions involve such images in the Timaeus. ${ }^{\circ} \mathrm{A}$ further remark by Aristotle in his discussion of anger confirms this reading. He says that spirited anger is attended by a certain sort of pleasure, "because thought dwells upon the act of vengeance, and the images then called up cause pleasure, just like the images called up in dreams" ( $R h$. I $378 \mathrm{~b} 8-\mathrm{IO})$. The fact that dreams provide the model for Aristotle's understanding of the sort of phantasia involved in anger shows that he has imagistic content in mind. ${ }^{4 \mathrm{I}}$ For both Aristotle and Plato, then, mental images that depict objects, actions, and situations of special concern to the non-rational elements of our souls are saliently involved in the emotions for which those elements are responsible. We can perhaps draw a further connection between the two theories, however (though somewhat more speculatively): The prominent role of imagination in Aristotle's account of the emotions suggests that the appetitive and spirited elements of the soul are distinctively responsive to mental imagery, in a way (or to an extent) that they might not be to non-imagistic, rational thoughts. Note that in the quotation offered above, it is not the mere thought (Stavoia) of revenge, but the mental image of revenge accompanying that thought, that causes spirited pleasure. This at least suggests that in Aristotle, as in the Timaeus, spirited desires may respond not to the propositional content of rational judgments themselves, but rather to the imagistic instances of phantasia that arise alongside those judgments. ${ }^{42}$

${ }^{4 \circ} \mathrm{Cf}$. remarks in Lorenz, Brute, I 89; and Moss, "Pictures," 267.

${ }^{4} \mathrm{I} F u r t h e r$ overlap between the Platonic and Aristotelian accounts concerns the role of the heart and blood in sensory processes. Aristotle identifies the heart as the organ of perception and imagination (MA 702bI 5-2I, PA 647a25-32, 666aII-I 7), and, like Plato, he assigns to the blood an important function in acts of perceiving and imagining (Sens. 444a8-I6; PA 666aI7-I9, 666a35-bI). He explains the phenomenon of dreaming in terms of blood (Somn. 461a25-b30), for example, and blood may even act as an agent of transmission (see discussion in Lorenz, Brute, I 5 5n I6; Modrak, Power, 72-75; and Solmsen, "Nerves," I69-78). Significantly, Aristotle also identifies the heart as the organ of spirited emotion (DA $403 \mathrm{a} 3 \mathrm{I}-\mathrm{bI})$, and he offers an elaborate explanation of the natural cowardliness or spiritedness of animals in terms of the constitution of their blood (PA 650bI9-65 IaI4).

${ }^{42}$ At $E N$ I I 49a24-I I $50 a 8$ (cf. MM I 202bio-28) Aristotle describes the phenomenon of impetuous akrasia, which occurs when spirit "seems to hear, but to mishear, reason." Aristotle explains that "when reason or imagination informs us that we have been insulted or slighted, anger . . boils up 
644 JOURNAL OF THE HISTORY OF PHILOSOPHY 52:4 OCTOBER 2 OI 4

If this last point is only intimated in the case of Aristotle, however, it is explicit in the case of our second ancient thinker, Posidonius. According to the report of Galen, Posidonius aims to resolve some "puzzles" concerning emotional impulses that, from his point of view (and that of Galen), his Stoic predecessors failed to address adequately. His account is important because-as Galen takes pains to emphasize-Posidonius follows Plato in his account of the emotions and in his advocation of a tripartite psychology ${ }^{43}$ Galen himself, moreover, endorses both the Platonic account as well as the Posidonian account that he characterizes as Platonist. Galen quotes Posidonius:

I think that you may have noticed for long enough how we may be rationally convinced

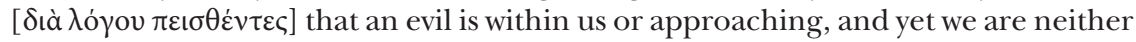

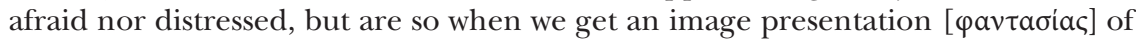
the evils themselves. You see, how could you move the irrational rationally, unless

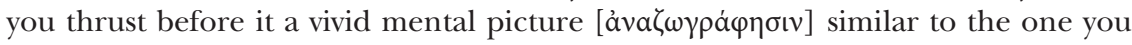
can see? Let me give you an example: there are cases of people tumbling into desire from a description; and some people are scared merely by a vivid injunction to take to their heels from a charging lion, even though they have not actually seen it. (PHP V.473-74, 453.I 5-454.7) 44

What Posidonius finds puzzling are cases in which our rational beliefs fail to align with our emotions. His solution is to drive a wedge between judgments on the one hand and emotional impulses on the other. The latter, unlike the former, are "irrational" and thus not responsive to rational considerations or logistic content. Instead, they respond exclusively to "mental pictures" and imagistic content. If we judge that evil is near without also vividly "picturing" it, therefore, our judgment will fail to stimulate our emotional reactions. ${ }^{45}$ Galen adds his endorsement to the above: "Posidonius' statements here are correct" (PHP V.474, 454.7-8). For Posidonius and Galen, who purport to be following Plato, our irrational emotions and desires respond not to rational judgments, but to the mental images that

straightaway." One might take this to imply that spirit responds directly to rational thoughts. However, this reading is not necessarily required by the text. Because all thought involves applications of imagination for Aristotle ( $D A 427$ bI 4-6, 43 IaI 6-7), it is possible that mental images are saliently involved in rousing spirit in both cases, and that the distinction Aristotle has in mind in referring to "reason or imagination" is between imagistic impressions of insult that arise alongside, or because of, reason's own judgments, and similar impressions that arise independently of, contrary to, or in the absence of, any relevant rational judgment. Cf. Lorenz, Brute, I9I-94 and n. 22, and the excellent treatment of impetuous anger in Grönroos, "Listening," which responds to Cooper, "Remarks," and "Moral Value," 26I-63.

${ }^{43}$ See esp. PHPIV.42 I, 396.I6-397.5; cf. V.48I, 462.I 2-463.6 and V.429, 405.9-I I. Posidonius accepts three distinct psychic faculties, even if not three distinct psychic parts (PHPV.454-55, 432.9-I 5 , and VI.5 I 5, 50I.7-I4).

${ }^{44}$ Translation of Posidonius is from Kidd, Translation. See discussion of this passage in Cooper, "Posidonius on Emotions," 473n39, and Kidd, Commentary, bk. 2, 578-79.

${ }^{45}$ The responsiveness of our emotional impulses to mental images is also reflected in Posidonius's account of moral education. He observes that the greatest emotional disturbances are caused by events and circumstances that are unexpected or to which we are unaccustomed. We can mitigate the effects of such events, however, by "living with things in advance." Galen explains, "Posidonius means by this ... to imagine beforehand as it were, and prefigure in our mind what is going to happen, and so gradually bring about a kind of habituation to it" (PHP IV.I7-I 8, 392.5-393.5). 
illustrate those judgments. Evidently, then, among Platonists an imagistic reading of Plato was considered a natural and attractive way to interpret Platonic psychology. ${ }^{6}$

\subsection{Objections}

To return to Plato's account, there is a worry that might arise about the imagistic proposal: If spirit responds not to propositional content, but rather to images that illustrate that content, then why does Plato use language that implies verbal communication? Why does spirit respond to reason's "commands," and why does it "listen to" or "obey" them? There are two points to note here. The first is that Timaeus employs the metaphorical language of war heavily throughout his account. Thus, for example, he says that the "bile and serum and phlegm of every sort" that contaminate our veins in times of disease "are hostile to one another ... and they wage a destructive and devastating war against the constituents of the body that have stayed intact and kept to their post" (83a). This language is especially prevalent in Timaeus's characterization of the spirited part of the soul, whose function is clearly supposed to parallel that of the guardians of the city whom Socrates describes at the beginning of the dialogue (during his summary of the characters' previous conversation). Just as the guardians of the city are to protect the city against injustice, "whether it be from someone outside or even

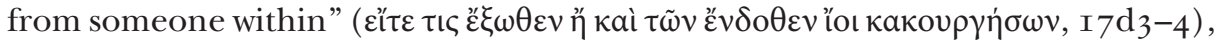
so the spirited part of the soul is stationed in the "guardhouse," where (with impeccable parallelism) it protects the individual against injustice, "whether it

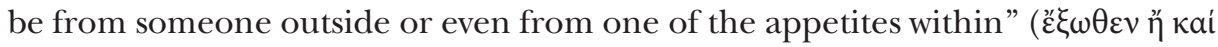
$\tau \iota \varsigma$ àmò $\tau \tilde{\omega} v \ddot{\varepsilon} v \delta$ o $\theta \varepsilon v \dot{\varepsilon} \pi\left(\theta v \mu \iota \tilde{\omega} v, 70 b_{5}\right) .{ }^{47}$ The martial metaphor makes the language

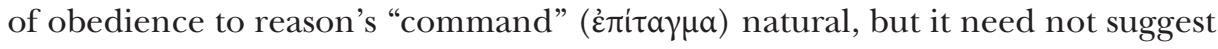
that spirit responds directly to the same sort of verbal command as does a soldier.

There is another good reason for Timaeus's use of language that implies verbal content, however: such content does, in fact, play an important role in reason's communications with spirit. According to the imagistic account, rational judgments are themselves formulated in propositional form, and it is those judgments that come to be represented imagistically in a way that is cognitively accessible to spirit. Therefore, just like the writings of the scribe that the painter illustrates in the Philebus, the verbal content of reason's judgments plays a crucial role in generating the images that result from it. Therefore, while we need not conclude

\footnotetext{
${ }^{46}$ Schiefsky ("Galen," 347-49) provides an illuminating discussion of the role of imagination in Galen's Platonist account of non-rational motivation and cognition.

${ }^{47}$ Taylor (Commentary, 500-503) draws attention to a number of ways in which Timaeus's characterization of spirit and its related physiology is intended to maintain the analogy to the guardians of the city: (I) Timaeus locates spirit "in the chest, in what is called the trunk," where the word for "trunk," $\theta \dot{\omega} \rho \alpha \xi$, is also a military term for the breastplate. (2) In Timaeus's reference to a "guardhouse" stationed near the "Acropolis," "Өvpó

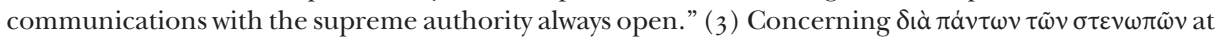
70b5-6: "The language ... is purposely chosen to keep up the original metaphor. The royal 'guards' are thought of as making their way into all the narrow alleys of the city to quell a disturbance."
} 
from Timaeus's account that spirit itself understands verbal content, nor do we need to explain away the presence or significance of such content..$^{8}$

One further point about the imagistic account is best brought out by an objection raised by Bobonich. His worry is that images are too ambiguous or indeterminate to do the work that imagistic accounts require of them. He provides the example of an appetitive desire for a soy burger and considers the mental image that might accompany that desire. "In the given picture," he writes, "the soy burger is, say, round, sitting on a plate, very thick, and has tomato on it. Is this a desire for a round soy burger or one of any shape? Do I want it on a plate or not? Thick or not?" 49 The problem he raises is that when we imagine something that we desire, the image we entertain will contain a number of features that are irrelevant as far as our desire is concerned. For that reason, he claims, mental images cannot specify the content of our desires. While Bobonich may be right to make this observation, it does not represent an objection to the imagistic account I have proposed. The reason is that, according to my view, the role of mental images is not to specify the content of non-rational desires, but rather to stimulate non-rational desires (or aversions) by putting the lower parts of the soul into cognitive contact with objects that they are antecedently inclined to find attractive (or repulsive).$^{50}$ In this regard, imagination does not work very much differently from sense-perception. If a person desired a soy-burger and saw one in front of her, the content of her perceptual experience would, like the mental image discussed by Bobonich, contain features that are irrelevant to her desire (it is on a plate, is served with a garnish, etc.). We could not, therefore, with complete specificity answer the question, "What is her desire a desire for?" simply by examining the content of her perceptual experience.

${ }^{48} \mathrm{We}$ have seen how rational judgments and thoughts can generate non-rational motivational states by means of the mental images that accompany and illustrate them. One question that arises out of this account is whether non-rational motivations require rational judgments and thoughts. Can spirited anger, for instance, arise all by itself, without the intervention of reasoning, or does it arise only if reason has issued an appropriate "command"? Although nothing in the account I have offered depends on how one answers this question (since my account concerns only those cases in which spirited desires $d o$ arise in response to reason), there are several reasons for thinking that non-rational motivations in general do not require rational judgment: (I) The possibility of psychic conflict between reasoning and the lower soul-parts suggests that they are capable of responding to perceptual and imaginative content other than that which illustrates reason's judgments. (2) Reflections on the psychology of animals, which do not engage in reasoning, evidently requires that non-rational soul-parts can have experiences and motivate agents independently of rational processes. (3) At 7od-e the appetitive part of the soul is given a special responsibility for the imaginative experiences that constitute dreaming, which take place when "the power of understanding is bound in sleep" (cf. Rep. 57 Ic-572b). This evidently shows that mental images can arise in the absence of any rational reflection-that, in the language of the Philebus, we sometimes find "paintings" in our souls without corresponding works of the "scribe." (4) On my account, rationally-induced mental images stimulate non-rational motivations by depicting objects and actions that attract or repel spirit and appetite. Similarly, spirited and appetitive motivations will arise when attractive or repulsive objects and actions present themselves directly through sense-perception itself (see discussion below and n. 5I). Hence even if-contrary to the third point-the use of imagination required reason's activity, non-rational motivations could still arise independently of reasoning, directly as a result of sense-perception. (See support in Plotinus, Ennead 4.4.35-54.)

49"Images," I 52.

${ }^{5 \circ} \mathrm{Cf}$. Phil. $34 \mathrm{~d}-35 \mathrm{~d}$, where desire is possible only if the soul "makes contact" with the object of its desire through memory. 
In the case of both perception and imagination, however, the point is that some features of the perceptual experience or mental image will be motivationally salient to us-that is, they will be the features of the perceived or imagined object that we actually desire (or are averse to) - and it is those features that will stimulate our non-rational desires and make us pursue (or avoid) the object in question. ${ }^{51}$

\section{C O N C L U S I O N : WH Y S P I R I T ?}

According to the imagistic account, all communication between reason and the mortal soul-parts, including communication between it and spirit, takes the form of quasi-perceptual representations or images: when our rational judgments about what we should do or avoid doing are accompanied by mental images depicting the recommended action in ways that appeal to, or repel, the appetitive or spirited parts of our souls, then those images will give rise to the appropriate appetitive or spirited motivations. Where the spirited and appetitive parts of our souls differ is that, although they both share in an awareness of the mental images we entertain, they respond to those images differently. This brings us to the second of the key questions raised at the start of this paper: Why is the spirited part of the soul responsive to the commands of reason in a way that the appetitive part is not?

Two points about education provide an important start to answering this question. First, while spirited desires are educable in the way outlined above, appetitive desires are not similarly educable. This difference between them is due to the fact that, because spirited desires aim at honor and self-esteem, they can be molded according to what is treated with honor and esteem in the individual's culture. Appetitive desires, by contrast, are inextricably linked to bodily processes of nourishment and reproduction and to physical feelings of pleasure and pain. The appetitive part of the soul, Timaeus says, desires "food and drink and whatever

${ }^{51}$ Bobonich ("Images," I 65-67) however, suggests that perceptual experiences themselves may be dependent on the mediation of reasoning. He appeals to Tim. 64b3-6, where Timaeus, discussing sense-perception, says, "When even a minor disturbance affects that which is easily moved by nature,

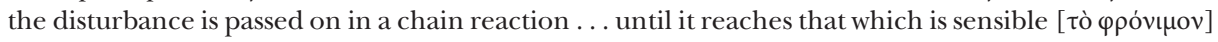

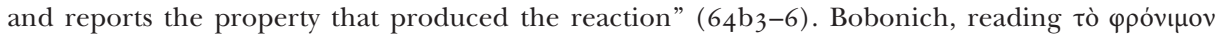
(plausibly, I take it) as a reference to the reasoning part of the soul, takes Timaeus's comment to show that perceptual experiences do not occur without reason's involvement: "Pleasure, as such, only has psychic effects when the immortal part has the necessary awareness of the relevant motions.... [They] count as pleasures and enter into their typical psychic interactions, for example, giving rise to certain desires, only with this contribution of the immortal part." (Cf. Lautner, "Hearing," 247.) The passage in question, however, underdetermines the strong conclusion Bobonich draws from it. What $64 \mathrm{~b}$ actually says is that the pathêmata that bring about the soul's perceptual experiences extend to the reasoning part; it does not say that there are no perceptual experiences until and unless those pathêmata extend to the reasoning part. We could easily read the passage as indicating simply the plausible point that perceptual experiences affect, and are common to, the entire soul, including its rational part (cf. Rep. 462c-d; Phil. 34a). Certainly we do not have beliefs about our experiences until those experiences reach our rational part, but that is not the same as having no experiences at all. (Cf. remarks in Frede, "Observations," 7.) We might also note the fact that Timaeus's "chain reaction"

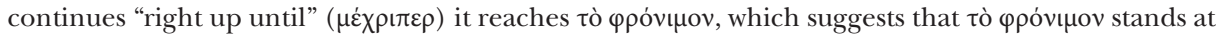
the conclusion of the process that constitutes perceptual experience, rather than at its beginning as its partial cause. For further discussion of tò $\varphi$ póvıov, see Carpenter, "Embodied"; Ganson, "Platonic Approach," 9; Gill, "Galen vs. Chryssipus," 269; Karfík, "Mortal Parts," 205; Lautner, "Hearing," 243 and nn. I9-20; O’Brien, Weight, I40n33; and Silverman, "Perception," I 52. 
else it needs on account of the body's nature," and he identifies sexual indulgence as "a disease of the soul" caused by a corrupt bodily condition (7od $\left.7-8,86 \mathrm{~d}_{3}-5\right)$. Likewise, in the Republic Socrates attributes appetitive desires to "disturbances

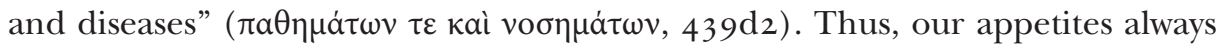
remain to a large extent at the mercy of brute facts about our physiology and the passive experiences affecting the body. ${ }^{52}$ And while we may be able to influence our physiology in various ways-Timaeus recommends exercising our bodies and souls so as to make them "proportionate" to each other, just as the motions of our three soul-parts should be made "proportionate" to one another-there is always a danger of misalignment between the bodily states that largely determine our appetitive desires and aversions, on the one hand, and our rational judgments about what is best, on the other. ${ }^{53}$ This is especially true given that our appetites, being rooted in bodily needs and depletions, tend to have an urgency that makes them seek immediate gratification, whereas our rational deliberations, being about "what is good for one and all," take into account the long-term as well as the short. ${ }^{54}$ When misalignment does occur between our appetites and reasonwhen appetite seeks some action that reason judges harmful, indecent, or bad in the long-run-it has no recourse except to "threaten" appetite by drawing its attention to the painful or unpleasant features of the action, and if that fails to forcibly suppress appetite with spirit's help.

There is, of course, an analogous possibility of misalignment between reason and spirit as well. If reason recommends some course of action, but it is the kind of action that the person, as a result of her upbringing and education, has come to associate with dishonor and shame, then the person's spirit will be disinclined to cooperate with reason. ${ }^{55}$ However, this kind of misalignment is significantly less likely than that between rational and appetitive desires. The reason for that, and this is the second point about education, is that our rational judgments about what is good tend to be lined up with our judgments and impressions about what is honorable in a way that they do not tend to be lined up with our judgments about what is pleasurable, gratifying to hunger or thirst, physically satisfying, etc. Nor is this tendency for alignment a coincidence. As the passage from the Republic quoted above indicates, Plato thinks that what kind of life a person lives and what kind of person he becomes is almost determined by the things that are granted praise and blame in his society. It is almost impossible, Plato thinks, to counteract the effects of this influence on a young person with any kind of private teaching. This is just to

${ }^{52}$ See also discussion in Moss, "Shame," I 62-63.

${ }^{53} \mathrm{This}$ is not to say that culture cannot influence appetitive desires at all. Indeed, Socrates's discussion of the degenerate regimes of Republic 8-9 (especially his characterization of democracy) shows that increasing variety of opportunities for pleasure in a society gives rise to increasingly diverse pleasures. However, the crucial difference is that in the case of appetite, culture can only have a negative impact on appetitive desires, by giving rise to various "unnatural" and "lawless" desires. The "natural" desires arise independently of culture and cannot be eliminated. I am grateful to an anonymous referee for drawing my attention to this point.

${ }^{54} \mathrm{Cf}$. Socrates's discussions at Prot. 35 6a-e and Phil. 4Id-42c.

${ }_{55}^{5}$ Thus Socrates indicates that spirit is the "natural" ally of reason, "provided that it has not been corrupted by a bad upbringing" (Rep. 44Ia2-3). 
make the plausible (perhaps obvious) point that we learn what is morally good or bad primarily by observing which kinds of actions and individuals are either praised and treated with honor or blamed and treated with punishment and dishonor. ${ }^{56}$ That is, what we grow up from early childhood admiring and praising, and seeing others admire and praise, will tend to be what we judge "good" as we mature and become increasingly rational individuals. ${ }^{57}$ This is true, of course, whether we are raised in a society in which what is truly morally good is treated with honor or not. Our judgments about what is pleasurable or immediately satisfying to our appetitive urges, on the other hand, do not have a similarly prominent and inevitable impact on our settled moral judgments. Therefore, while reason's "commands" about what is best will, as a general rule, tend to appeal more or less reliably to spirit's desire for honor, they will not necessarily appeal to the body-dependent desires of appetite. Spirit and appetite may both "perceive" reason's commands, as the imagistic account has it, but only spirit is specially suited to obey and execute those commands: only spirit is reason's "ally" in the soul..$^{8}$

A B B REVIATIONS OF ARISTOTLE'S WORKS:

$\begin{array}{ll}\text { DA } & \text { De Anima } \\ \text { Insom. } & \text { De Insomniis } \\ \text { MA } & \text { De Motu Animalium } \\ \text { Mem. } & \text { De Memoria } \\ \text { MM } & \text { Magna Moralia } \\ \text { EN } & \text { Ethica Nicomachea } \\ \text { PA } & \text { De Partibus Animalium } \\ \text { Sens. } & \text { De Sensu et Sensibilibus } \\ \text { Somn. } & \text { De Somno }\end{array}$

A B B REVIATION OF GALEN'S WORK:

PHP De Placitis Hippocrates et Platonis

A B B REVIATIONS OF PLATO'S WORKS:

$\begin{array}{ll}\text { Phdr. } & \text { Phaedrus } \\ \text { Phil. } & \text { Philebus } \\ \text { Prot. } & \text { Protagoras } \\ \text { Rep. } & \text { Republic } \\ \text { Soph. } & \text { Sophist } \\ \text { Tht. } & \text { Theaetetus } \\ \text { Tim. } & \text { Timaeus }\end{array}$

${ }^{56}$ For more elaborate accounts of this phenomenon, see Moss, "Shame," and Lear, "Learning." Singpurwalla ("Fine") offers a dissenting interpretation of spirit's relationship with reason.

${ }^{57} \mathrm{Cf}$. Rep. 4 OId-402a, where Socrates characterizes early musical education as the process in which the young person comes to admire and feel shame toward the right things "while he's still young and unable to grasp the reason, but, having been educated in this way, he will welcome the reason when it comes and recognize it easily because of its kinship with himself."

${ }^{58}$ Very early versions of this paper benefited greatly from the feedback of John Cooper, Hendrik Lorenz, Alexander Nehamas, Brad Inwood, and Emily Austin. The present version benefited from the feedback of my anonymous referees. 


\section{O T HER SOURCES :}

Anagnostopoulos, Mariana. "The Divided Soul and the Desire for Good in Plato's Republic." In Santas, Blackwell, I67-88. ["Divided Soul"]

Annas, Julia. An Introduction to Plato's Republic. Oxford: Clarendon Press, I98 I. [Introduction]

Archer-Hind, R. D. The Timaeus of Plato. New York: Arno Press, I973.

Barnes, Jonathan. The Complete Works of Aristotle. 2 vols. Princeton, NJ: Princeton University Press, I984. [Complete Works]

Barney, Rachel. "Appearances and Impressions." Phronesis 37 (I992): 283-3 I3. ["Appearances"]

Barney, Rachel, Tad Brennan, and Charles Brittain, eds. Plato and the Divided Self. Cambridge: Cambridge University Press, 20I 2. [Divided Self]

Bobonich, Christopher. "Akrasia and Agency in Plato's Laws and Republic." Archiv für Geschichte der Philosophie 76 (1979): 3-36. ["Agency"]

—_. "Images of Irrationality." In Bobonich, Critical Guide, I 49-7 I. ["Images"]

— ed. Plato's Laws: A Critical Guide. Cambridge: Cambridge University Press, 20 Io. [Critical Guide] Plato's Utopia Recast: His Later Ethics and Politics. Oxford: Oxford University Press, 2002. [Utopia]

Bobonich, Christopher, and Pierre Destrée, eds. Akrasia in Greek Philosophy: From Socrates to Plotinus. Leiden: Brill, 2007. [Greek Philosophy]

Brennan, Tad. "The Nature of the Spirited Part of the Soul and its Object" In Barney, Brennan, and Brittain, Divided Self, I02-27. ["Spirited Part"]

Brisson, Luc. "Plato's Theory of Sense Perception in the Timaeus: How It Works and What It Means." In Cleary and Gurtler, Proceedings, I47-76. ["Sense Perception"]

Cairns, Douglas L. Aidôs: The Psychology and Ethics of Honour and Shame in Ancient Greek Literature. Oxford: Clarendon Press, I993. [Psychology]

Carone, Gabriela Roxana. "Akrasia and the Structure of the Passions in Plato's Timaeus." In Bobonich and Destrée, Greek Philosophy, Iо I-I8. ["Passions"]

Carpenter, Amber D. "Embodied Intelligent (?) Souls: Plants in Plato's Timaeus." Phronesis 55 (2010): 28 I-303. ["Embodied"]

Caston, Victor. "Why Aristotle Needs Imagination." Phronesis 6I (I996): 20-55. ["Imagination"]

Cleary, John, and Gary Gurtler, eds. Proceedings of the Boston Area Colloquium in Ancient Philosophy, vol. I3. Leiden: Brill, I999. [Proceedings]

Cooper, John M. "An Aristotelian Theory of the Emotions." In Cooper, Reason and Emotion, 406-23. ["Emotions"]

, ed. Plato: Complete Works. Indianapolis: Hackett Publishing Company, 1997.

. "Plato's Theory of Human Motivation." In Cooper, Reason and Emotion, I I 8-37. ["Theory"]

. "Posidonius on Emotions." In Cooper, Reason and Emotion, 449-84.

, ed. Reason and Emotion. Princeton, NJ: Princeton University Press, I999.

Value"]

—. "Some Remarks on Aristotle's Moral Psychology." In Cooper, Reason and Emotion, 237-52. ["Remarks"]

Cornford, F. M. Plato's Cosmology: The Timaeus of Plato. London: Routledge, I937. [Plato's Cosmology]

Cross, R. C., and A. D. Woozley. Plato's Republic: A Philosophical Commentary. London: The Macmillan Press, I964. [Philosophical Commentary]

Delcomminette, Sylvain. "False Pleasures, Appearances, and Imagination in the Philebus." Phronesis 48 (2003): 2I 5-37. ["False Pleasures"]

Dodds, E. R. The Greeks and the Irrational. Berkeley: University of California Press, I95 I. [Irrational]

Dybikowski, J. "False Pleasure and the Philebus." Phronesis I 5 ( I970): I47-65. ["False"]

Evans, Matt. "Plato on the Possibility of Hedonic Mistakes." Oxford Studies in Ancient Philosophy 35 (2008): 89-I 24. ["Hedonic"]

Everson, Stephen. Aristotle on Perception. Oxford: Clarendon Press, I997.

Fortenbaugh, W. W. Aristotle on Emotion. London: Duckworth, I975.

Frede, Dorothea. "The Cognitive Role of Phantasia in Aristotle." In Nussbaum and Rorty, Aristotle's De Anima, 279-95. ["Cognitive"]

. "Rumpelstiltskin's Pleasures: True and False Pleasures in Plato's Philebus." Phronesis 30 (I985): I 5 I-80. ["Pleasures"] 
Frede, Michael. "Observations on Perception in Plato's Later Dialogues." In Essays in Ancient Philosophy, edited by Michael Frede, 3-7. Minneapolis: University of Minnesota Press, I987. ["Observations"]

Ganson, Todd. "The Platonic Approach to Sense-Perception." History of Philosophy Quarterly 22 (2005): I-I 5. ["Platonic Approach"]

- "The Rational/Non-Rational Distinction in Plato's Republic." Oxford Studies in Ancient Philosophy 36 (2009): I79-97. ["Rational/Non-Rational"]

Gallop, David. Aristotle on Sleep and Dreams. Lewiston, NY: Broadview Press, I990. [Sleep]

Gill, Christopher. "Galen vs. Chrysippus on the Tripartite Soul in Timaeus 69-72." In Interpreting the Timaeus-Critias: Proccedings of the IV Symposium Platonicum: Selected Papers, edited by L. Brisson and T. Calvo, 267-73. Sankt Augustin: Academia Verlag, I997. ["Galen vs. Chrysippus"]

Gosling, J. C. B. "False Pleasures: Philebus 35c-4 Ib." Phronesis 6 (I959): 44-54. ["Philebus 35c-4 Ib"] Plato. London: Routledge and Kegan Paul, I973.

Gosling, J. C. B., and C. C. W. Taylor. The Greeks on Pleasure. Oxford: Clarendon Press, I982.

Graham, Daniel W. The Texts of Early Greek Philosophy. 2 vols. Cambridge: Cambridge University Press, 2010. [Early Greek Philosophy]

Grönroos, Gösta. "Listening to Reason in Aristotle's Moral Psychology." Oxford Studies in Ancient Philosophy 32 (2007): 25 I-7I. ["Listening"]

Hardie, W. F. R. A Study in Plato. Oxford: Clarendon Press, 1936.

Harte, Verity. "The Philebus on Pleasure: The Good, the Bad, and the False." Proceedings of the Aristotelian Society IO4 (2004): I I I-28. ["Philebus on Pleasure"]

Hobbs, Angela. Plato and the Hero: Courage, Manliness and the Impersonal Good. Cambridge: Cambridge University Press, 2000. [Hero]

Irwin, Terence. Plato's Ethics. Oxford: Oxford University Press, I995. [Ethics]

Johansen, Thomas. "Body, Soul, and Tripartition in Plato's Timaeus." Oxford Studies in Ancient Philosophy 29 (2000): 87-I I I. ["Body"]

. Plato's Natural Philosophy: A Study of the Timaeus-Critias. Cambridge: Cambridge University Press, 2004. [Natural Philosophy]

Kahn, Charles. "From Republic to Laws: A Discussion of Christopher Bobonich, Plato's Utopia Recast." Oxford Studies in Ancient Philosophy 26 (2004): 337-662. ["Discussion"]

Kamtekar, Rachana. "Imperfect Virtue." Ancient Philosophy I8 (I998): 3 I 5-39.

. "Psychology and the Inculcation of Virtue in Plato's Laws." In Bobonich, Critical Guide, I27-48. ["Inculcation"]

Karfík, Filip. "What the Mortal Parts of the Soul Really Are." Rhizai 2 (2005): I97-2 I7. ["Mortal Parts"]

Kenny, Anthony. "False Pleasures in the Philebus: A Reply to Mr. Gosling." Phronesis 5 (I960): 45-52. ["Reply"]

Kidd, I. G. Posidonius. Vol. 2, bk. I-2, The Commentary. Cambridge: Cambridge University Press, I988. [Commentary]

Posidonius. Vol. 3, The Translation of the Fragments. Cambridge: Cambridge University Press, I999. [Translation]

Lautner, Péter. "The Timaeus on Sounds and Hearing with Some Implications for Plato's General Account of Sense-Perception." Rhizai 2 (2005): 235-53. ["Hearing"]

Lear, Gabriel Richardson. "Plato on Learning to Love Beauty." In Santas, Blackwell, I04-24. ["Learning"]

Lesses, Glenn. "Weakness, Reason, and the Divided Soul in Plato's Republic." History of Philosophy Quarterly 4 (I987): I47-6r. ["Weakness"]

Lorenz, Hendrik. The Brute Within: Appetitive Desire in Plato and Aristotle. Oxford: Oxford University Press, 2006. [Brute]

"The Cognition of Appetite in Plato's Timaeus." In Barney, Brennan, and Brittain, Divided Self, $238-58$. ["Cognition"]

Miller, Dana R. "Commentary on Brisson.” In Cleary and Gurtler, Proceedings, I77-8 5 .

Modrak, Deborah. Aristotle: The Power of Perception. Chicago: University of Chicago Press, I987. [Power]

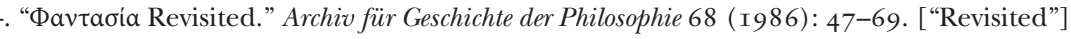

Moline, J. "Plato on the Complexity of the Psyche." Archiv für Geschichte der Philosophie 60 (I978): I-26. ["Complexity"]

Morris, Michael. "Akrasia in the Protagoras and the Republic." Phronesis 5I (2006): I95-229. ["Akrasia in the Protagoras"]

Morrow, Glenn. "Plato's Conception of Persuasion." Philosophical Review 62 (I953): 234-50. ["Conception"]

Moss, Jessica. "Pictures and Passions in the Timaeus and Philebus." In Barney, Brennan, and Brittain, Divided Self, 259-80. ["Pictures"] 
652 JOURNAL OF THE HISTORY OF PHILOSOPHY 52:4 OCTOBER 2OI 4

. "Shame, Pleasure, and the Divided Soul." Oxford Studies in Ancient Philosophy 29 (2005): I37-70. ["Shame"]

Nehamas, Alexander. "Pity and Fear in the Rhetoric and the Poetics." In Essays on Aristotle's Poetics, edited by A. Rorty, 29I-3 I4. Princeton, NJ: Princeton University Press, I992. ["Pity"]

Nieuwenburg, Paul. "Emotion and Perception in Aristotle's Rhetoric." Australasian Journal of Philosophy 80 (2002): 86-100. ["Emotions and Perception"]

Nussbaum, Martha. Aristotle's De Motu Animalium. Princeton, NJ: Princeton University Press, I978. [Aristotle's De Motu]

- "Aristotle on Emotions and Rational Persuasion." In Rorty, Aristotle's Rhetoric, 303-23. ["Rational Persuasion"]

Nussbaum, Martha, and Amélie Oksenberg Rorty, eds. Essays on Aristotle's De Anima. Oxford: Clarendon Press, I992. [Aristotle's De Anima]

O'Brien, D. Theories of Weight in the Ancient World. Vol. 2, Plato: Weight and Sensation. Leiden: Brill, I984. [Weight]

Penner, Terrence. "False Anticipatory Pleasure: Philebus 36a3-41a6." Phronesis I 5 (1970): I66-78. ["Anticipatory"]

Price, A. W. "Are Plato's Soul-Parts Psychological Subjects?" Ancient Philosophy 29 (2009): I-I 5. ["Subjects"]

Reeve, C. D. C. Blindness and Reorientation. Oxford: Oxford University Press, 2013. [Reorientation]

. Philosopher-Kings: The Argument of Plato's Republic. Princeton, NJ: Princeton University Press, I988. [Philosopher-Kings]

Rorty, Amélie Oksenberg, ed. Essays on Aristotle's Rhetoric. Berkeley: University of California Press, I996. [Aristotle's Rhetoric]

Russell, Daniel. Plato on Pleasure and the Good Life. Oxford: Oxford University Press, 2005. [Good Life]

Santas, Gerasimos, ed. The Blackwell Guide to Plato's Republic. Malden, MA: Blackwell Publishing, 2006. [Blackwell]

Schiefsky, Mark. "Galen and the Tripartite Soul." In Barney, Brennan, and Brittain, Divided Self, 33 I-49. ["Galen"]

Schofield, Malcolm. "Aristotle on the Imagination." In Nussbaum and Rorty, Aristotle's De Anima, 249-77. ["Aristotle"]

Shields, Christopher. "Unified Agency and Akrasia in Plato's Republic." In Bobonich and Destrée, Greek Philosophy, 6I-86. ["Unified"]

Silverman, Allan. "Plato on Perception and 'Commons.'” The Classical Quarterly 40 (I990): I48-75. ["Perception"]

Singpurwalla, Rachel. "Reasoning with the Irrational: Moral Psychology in the Protagoras." Ancient Philosophy 26 (2006): 243-58. ["Reasoning"]

. "The Tripartite Theory of Motivation in Plato's Republic." Philosophy Compass 5 (201 I): 880-92. ["Motivation"]

- "Why Spirit is the Natural Ally of Reason: Spirit, Reason, and the Fine in Plato's Republic." Oxford Studies in Ancient Philosophy 44 (20I3): 4I-65. ["Fine"]

Solmsen, Friedrich. "Greek Philosophy and the Discovery of the Nerves." Museum Helveticum I 8 (I96I): I 50-97. ["Nerves"]

Stalley, R. F. "Persuasion and the Tripartite Soul in Plato's Republic." Oxford Studies in Ancient Philosophy 32 (2007): 63-90. ["Persuasion"]

Striker, Gisela. "Emotions in Context: Aristotle's Treatment of the Passions in the Rhetoric and His Moral Psychology." In Rorty, Aristotle's Rhetoric, 286-302. ["Emotions in Context"]

Taylor, A. E. A Commentary on Plato's Timaeus. Oxford: Clarendon Press, I928. [Commentary]

Thein, Karel. "Imagination, Self-Awareness, and Modal Thought at Philebus 39-40." Oxford Studies in Ancient Philosophy 42 (20I2): I09-49. ["Self-Awareness"]

Wedin, Michael V. Mind and Imagination in Aristotle. New Haven, CT: Yale University Press, I 988 . [Mind] Wilburn, Josh. "Moral Education and the Spirited Part of the Soul in Plato's Laws." Oxford Studies in Ancient Philosophy 45 (2013): 63-IO2. ["Education"] 